Quarterly Journal of the Geological Society

\title{
On Ailurus anglicus, a new Carnivore from the Red Crag
}

W. Boyd Dawkins

Quarterly Journal of the Geological Society 1888, v.44; p228-231.

doi: 10.1144/GSL.JGS.1888.044.01-04.20

$\begin{array}{ll}\begin{array}{l}\text { Email alerting } \\ \text { service }\end{array} & \begin{array}{l}\text { click here to receive free } \\ \text { e-mail alerts when new articles } \\ \text { cite this article }\end{array} \\ \begin{array}{l}\text { Permission } \\ \text { request }\end{array} & \begin{array}{l}\text { click here to seek permission } \\ \text { to re-use all or part of this } \\ \text { article }\end{array} \\ \text { Subscribe } & \begin{array}{l}\text { click here to subscribe to } \\ \text { Quarterly Journal of the } \\ \text { Geological Society or the Lyell } \\ \text { Collection }\end{array}\end{array}$

\section{Notes}

(C) The Geological Society of London 2013

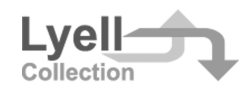


18. On Ailuros anautus, a new Cariviore from the Red Crae. By W. Bord Dawkins, F.R.S., Professor of Geology and Palaontology in Owens College. (Read January 25, 1888.)

81. Introductory.

2. Description and Comparison with Ailurus fulgens.

8. Measurements.

4. Ravge of Ailurus in Space and in Time.

[Plate X.]

\section{§1. INTRODUCTORY.}

Is the fine collection of fossils from the Crag of Norfolk and Suffolk, presented to the Museum of the Yorkshire Philosophical Society at York by Dr. Reed, is a battered and water-worn specimen, which is of singular interest, because it carries the range of one of the most restricted of the genera of the Oriental Province far to the west and to the north of its present habitat. It is a small fragment of the right lower jaw, with the last true molar in position, found in the Red Crag of Felixstowe, the rest of the ramus and the angle and articular and coronoid processes being broken away ( 800 figs. 1 and 2 ).

\section{§. Description and Comparibon with Aiturus fulgens.}

After a long and careful study, I find that the lower jaw in question differs in a marked degree from all the European fossil Carnivores, and presents no important points of difference when compared with the series of jaws of recent Ailurus in the British Museum.

The last true molar in the fossil is implanted in the jaw by two fangs, the anterior being the smaller, and supporting the snterior cusps, $\Delta$ and $D$ of figures $1,2,3,4$. The multicuspid crown is composed of three small, obtusely pointed cusps, A, B, c of figs. 1, 3, and 4, on the outer side, while the inner (figs. 2 and 3 ) is occupied by the large cusp $D$ and a smaller hind cusp $F$, connected by a line of low tubercles, from which the enamel has been stripped. The outer series of cusps is separated from the inner by a shallow longitudinal groove (fig. 3) traversing the crown nearer the inner than the outer side, and causing the inner cusps to be narrower than the outer. They are also the higher. The crown is also divided by two transverse valleys into three lobes (figs. 3,4 ), of which the anterior, $\Delta, D_{\text {, }}$ is the higher and larger. In all these points the fossil agrees with the living Ailurus (figs. 5, 6, and 7), with the exception that the longitudinal depression is not so strongly marked in the former.

Nor are differences of any value to be noted on a comparison of the fossil specimen with the recent teeth cusp by cusp. The anteroouter cusp $\triangle$ of figs. 3 and 4 occupies the greater part of the front lobe, and has in front a small talon or tubercular cingulum. In five specimens of living Ailurus the cusp $\mathrm{A}$ is in the same relative position (figs. 6 and 7), and a tubercular cingulum or slight talon is traceable in four. The accessory cusp $s^{\prime}$ of figs. 3 and 4 is present in 
PROF. W. BOPD DAWRING ON AILURUS ANGLICUS.

the interspace between $\triangle$ and $B$, in both the fossil and the reeent (figs. 6 and 7). The cusp $\mathrm{B}$ of the fossil is obtusely pointed and separated by a cleft from the third cusp c. Behind this cleft in the fossil is a small accessory cusp $\mathrm{B}^{\prime}$ (fig. 4), which I have only been able to note as a mere rudiment in one recent tooth belonging to an Ailurus shot by Mr. B. H. Hodgson in Nepaul. The third cusp, c, is small and mapped off from the back cusp $F$ by a slight valley. In all these points the fossil agrees with the recent specimens. On the inner side, the front lobe $D$ of fig. 3 is mapped off from $\Delta$ by a cleft, and bears a talon in front. In the living Ailurus (fig. 6), the talon has developed into a basal cusp $\mathrm{D}^{\prime}$. The fractured surface of the tooth (figs. 2 and 3 ) behind $\mathrm{D}$ renders it impossible to compare the inner margin minutely with the recent specimens; enough, however, remains to prove that it is composed of small tubercles running from $\mathbf{D}$ to $\mathbf{F}$, like those in Ailurus fulgens (fig. 6, ₹). The cusps of the fossil are, as a whole, larger, blunter, and less clearly defined from one another than in recent Ailuri.

On a comparison of the fossil with the recent jaws of Ailurus, the only marked point of difference is that the dental foramen is situated further back in the former than in the latter. These differences are not, in my opinion, of more than specific value; and I therefore propose the name of Ailurus anglicus for the fossil, from its discovery in East Anglia.

\section{§3. Measurements.}

The following Table gives the comparative measurements of the teeth and jaws of the fossil and recent Ailuri in inches and tenths.

True Molar 2.

\begin{tabular}{|c|c|c|c|}
\hline & \multirow[b]{2}{*}{$\begin{array}{c}\text { Ailurus } \\
\text { anglicus, } \\
\text { Dawkins. }\end{array}$} & \multicolumn{2}{|c|}{ Brit. Mus. } \\
\hline & & $\begin{array}{l}\text { Ailurus } \\
\text { fulgens, } \\
226 . \mathrm{h} \text {. }\end{array}$ & $\begin{array}{l}\text { Ailurus } \\
\text { fulgens, } \\
226 . \mathrm{g} .\end{array}$ \\
\hline $\begin{array}{l}\text { Length } \\
\text { Breadth of front lobe } \\
\text { Breadth of middle }\end{array}$ & $\begin{array}{l}0.70 \\
0.40+ \\
0.32+ \\
0.38+\end{array}$ & $\begin{array}{l}0.48 \\
0 \cdot 23 \\
0 \cdot 20 \\
0.15\end{array}$ & $\begin{array}{l}0.45 \\
0.22 \\
0.22 \\
0.15\end{array}$ \\
\hline
\end{tabular}

Thr Lower $\mathbf{J}_{\boldsymbol{\Lambda}} \mathbf{w}$.

\begin{tabular}{|c|c|c|c|}
\hline & \multirow[b]{2}{*}{$\begin{array}{l}\text { Ailurus } \\
\text { anglicus, } \\
\text { Dawkins. }\end{array}$} & \multicolumn{2}{|c|}{ Brit. Mus. } \\
\hline & & $\begin{array}{l}\text { Ailurus } \\
\text { fulgens, } \\
226 . \mathrm{h} \text {. }\end{array}$ & $\mid \begin{array}{l}\text { Ailurus } \\
\text { fulgens, } \\
226 . \mathrm{g} .\end{array}$ \\
\hline $\begin{array}{l}\text { Depth behind m } 2 \\
\text { Circumference } \\
\text { Depth in front of } \mathrm{m} 2 \\
\text { Circumference }\end{array}$ & $\begin{array}{l}0.95 \\
2.5 \\
0.87 \\
2.4\end{array}$ & $\begin{array}{l}0.81 \\
0.61\end{array}$ & $\begin{array}{l}0.75 \\
0.58\end{array}$ \\
\hline
\end{tabular}


From these measurements it is clear that the Ailurus from the Crag was a larger and more powerful animal than any of the recent Ailuri in the British Museum.

\section{\$4. The Range of Aulurus in Space and in Time.}

The living Ailurus, the "Wah" or "Panda," is a carnivore belonging to the Arctoidea, and standing, according to Flower*, between the Ursidæ and Procyonidæ. It is, according to Hodgson $\uparrow$, of exceedingly restricted range, being found in the sub-Himalayas, in which it lives in the deserts, between 7000 and 13,000 feet above the sea, ranging northwards on the flanks of the mountains as far as the forests extend, in Thibet, Nepaul, Sikkim, and Bhotan. It is described by Anderson + as infabiting the high and dry country to the north-east of Darjeeling $\S$. It ranges also as far to the east as Yunnan $\|$.

The discovery of the lower jaw described above extends the range of the genus, restricted at the preseut time to high altitudes in the regions north and east of India, to the shores of western Europe in the Pliocene age, and offers new evidence in support of the view 9 that the Pliocene Mammalia of Europe are closely related to those now living in the far East, in the Oriental Region. Of the associated genera found in the Red Crag, four-Ailurus, Tapirus (priscus), Cervus (suttonensis), and Rhinoceros (Schleiermacheri)-are represented by living forms in the Oriental Region, while two extinct genera, Hipparion and Hycenarctos, are common to the Pliocenes of India and Britain. From these facts I should conclude that the Oriental Region has offered a secure place of refuge to some of the Pliocene genera, in which they have survived the changes in their surroundings that have caused them to disappear from Europe and the rest of Asia.

\section{EXPLANATION OF PLATE $\mathbf{X}$.}

Fig. 1. Ailurus anglicus, Dawkins, right lower jaw, outer side. Nat. size.

2. The same, inner side.

3. The same, molar tooth, m. 2, surface of crown. $\times 2$.

4. The same, $\overline{\text { m. } 2}$, outer surface. $\times 2$.

5. Ailurus fulgens, F. Cuv., lower jaw, outer side. Nat. size.

6. The same, molar tooth, $\mathrm{m.2}$, surface of crown. $\times 2$.

7. The same, molar tooth, $\overline{\mathrm{m} .2}$, outer surface. $\times 2$.

* Elower, Proc. Zool. Soc. 1869, p. 37, 1870, p. 752; Encyclop. Britann. Article Mammalia; Section Arctoidea; Fam. 1, Mustelida; Fam. 2, Procyonide ; Fam. 3, Ailuride; Fam. 4, Urside.

+ B. H. Hodgson, Journ. Asiatic Soc. Bengal, rol. xvi. p. 1113 (1847).

$\ddagger$ J. Anderson, Proc. Zool. Soc. 1869 , pp. 278,$408 ; 1871$, p. 561 .

$\$$ For other information see Mivart, Proc. Zool. Soc. 1882, p. 135, and Bartlett, Proc. Zool. Soc. 1870, p. 769.

$\|$ Anderson 'Anatomical and Zoological Results of the Yunnan Expeditions,' Introd. p. xx. For this reference to its eastern range $I$ am indebted to the Referee.

I Dawkins, 'Early Man in Britain,' pp. 79, 89. 
Downloaded from http://jgslegacy.lyellcollection.org/ at Duke University on

January 20, 2013

Quart.Journ.Geol. Soc. Vol. XLIV. PI.X.
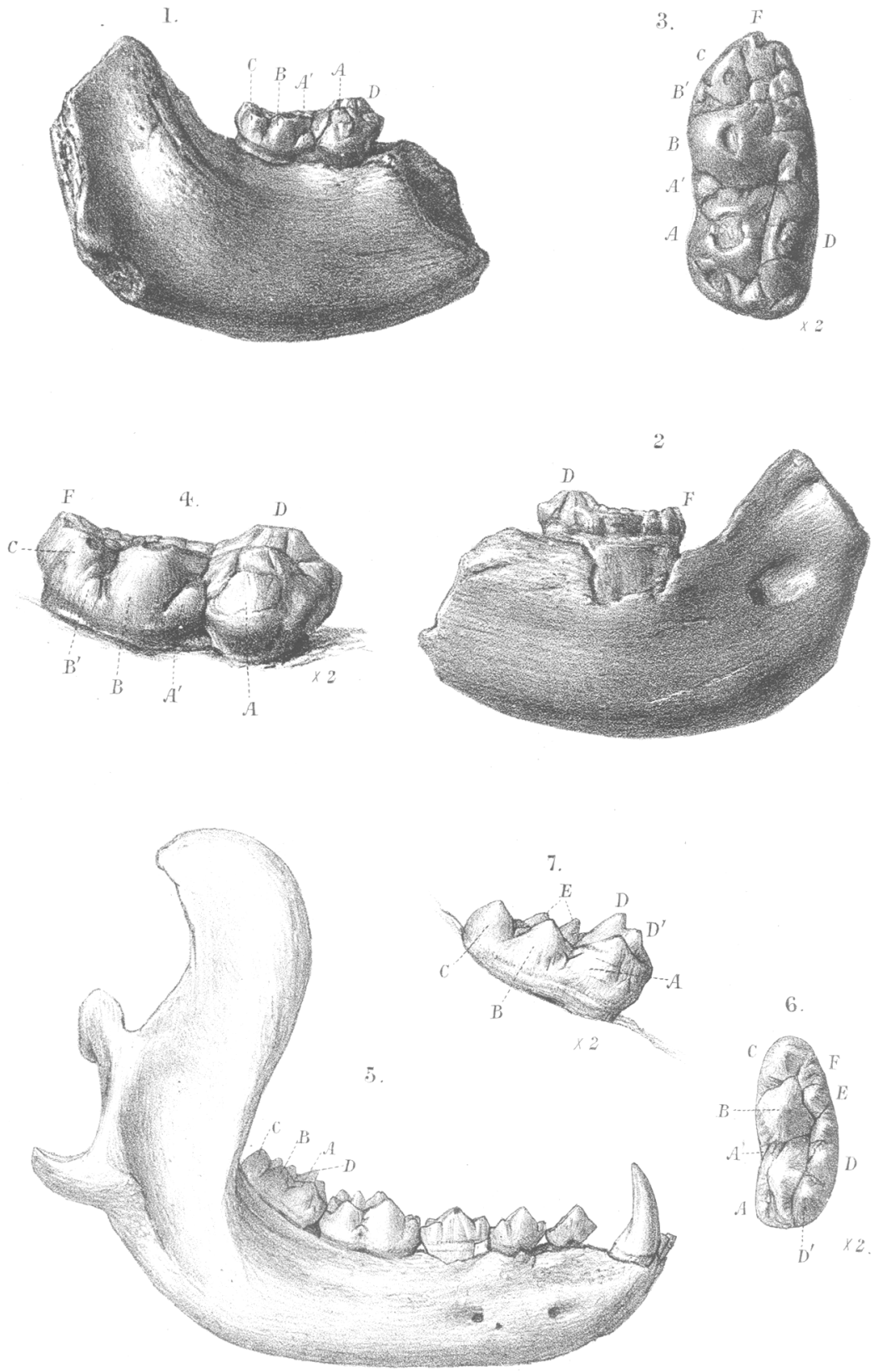

Mintern Bros. ims.

F. H. Michael del et lith. 
PROF. W. BOYD DAWRINS ON AILURUS ANGLICUS.

\section{Discussion.}

The Presidenr remarked that seldom had a fact of greater interest in its bearing upon geographical distribution in past times been brought before the Society.

Mr. LYDEKKER said that he had not much doubt as to the correctness of the identification; at any rate, the fossil seemed to indicate a genus closely allied to Ailurus. As shown by the molar, it could not apparently belong to any other group, no known Artiodactyle being like it. He rather differed as to the question of range. There is no trace of Ailurus in the Miocene or Upper Eocene of Europe, and he thought it more probable that the genus had reached Europe from India whilst missing Africa.

Prof. SEELEY said that although the tooth was worn, he considered that its crown was traversed by two longitudinal parallel grooves, defining three rows of denticles or cusps, while in Ailurus there was only a median groove between the denticles. $\mathrm{He}$ considered that the mode of grouping of the denticles in the recent and fossil types was different, so as to suggest even greater divergence in the other teeth which were not preserred. Differences of this kind were usually regarded as generic, and might have a family value. They are supported by differences in the coronoid process, in the way in which it arises, and in the form of the bony substance of the jaw. The fossil specimen was one third larger. So that, while he regarded the affiliation to Ailurus as a legitimate indication of affinity, he thought that the facts justified caution in making a generic determination, and that this was the more necessary if new views on geographical distribution were based upon the interpretation.

Mr. Newton, while admitting that it is desirable to be cautious before giving names, said he could find nothing like this tooth in the Crag, while its agreement with the corresponding tooth of Ailurus was very close indeed, excepting in the unimportant matter of size. With regard to the distribution, he referred to the Gazelle from the Upper Crag, which also found its nearest allies in Asiatic rather than in African forms.

Mr. BLANFond expressed his surprise at the discovery. The fact of the tooth being worn was of no importance. There was not much to be inferred from the Gazelle mentioned by Mr. Newton, as it represented an entirely different fauna. Ailurus was now confined to the Eastern Himalaya, and was, in fact, an Asiatic raccoon. If this fossil was really Ailurus, the range of the raccoons must have been more extended, and yet no other fossil species had been found in the old World, nor was there any representative of Ailurus in Africa. On the evidence, Prof. Dawkins was possibly right; but one tooth was not much to go upon; and, on the whole, the determination would require confirmation. 